\title{
State Space Agency of Ukraine: History of the Development of Normative Base
}

\author{
Yulia Iurynets \\ Doctor of Law, Associate Professor, National Aviation University (Kyiv, Ukraine) \\ E-mail: iurynetsjulia@ukr.net \\ https://orcid.org/0000-0003-0281-3251
}

\begin{abstract}
Space research is carried out in many countries. However, correct organization of this activity requires proper state regulation. In the paper, the authors reviewed the history of the creation of the normative base of the space agency of Ukraine. The study of documents that define and determined regulatory regulation of the organization of space activities in Ukraine allowed the authors to follow, on the one hand, the formation of the space industry of independent Ukraine, on the other - to identify the causes of the decline of the once leading in the USSR space industry. Independent Ukraine became the successor of most of the scientific developments, intellectual potential and industrial assets of the space industry of the USSR. However, it failed to take advantage of the potential that she got.
\end{abstract}

Keywords: space activities, central executive authorities, Ukraine Space Agency, space industry, normative base

\section{Державне космічне агентство України: історія розвитку нормативної бази}

\begin{abstract}
Юринець, Юлія Леонідівна
Доктор юридичних наук, доцент, Національний авіаційний університет
\end{abstract}

(Київ, Україна)

\begin{abstract}
Космічні дослідження здійснюються у багатьох краӥнах світу. Однак для ефективноі організації иієї діяльності потрібне належне державне регулювання. У статті автори розглянули історію створення нормативної бази космічного агентства Украйни. Дослідження документів, щзо визначали і визначають нормативне регулювання процедур організації космічної діяльності в Україні дозволило авторам прослідкувати, з одного боку, становлення космічної індустрії незалежної України, з другого - виявити причини занепаду колись провідної у СРСР космічної галузі. Незалежна Украӥна стала правонаступницею більшої частини наукових розробок, інтелектуального потенціалу і промислових активів космічної галузі СРСР. Однак, вона не змогла скористатися потенціалом, який їй дістався.
\end{abstract}

Ключові слова: космічна діяльність, иентральні органи виконавчої влади, космічне агентство України, космічна галузь

(C) Iurynets, Yulia, 2018 
Received: July 16, 2018; accepted: August 21, 2018

Advanced Space Law, Volume 2, 2018: 21-30.

https://doi.org/10.29202/asl/2018/2/3

\section{Постановка проблеми}

Космічні дослідження здійснюються у багатьох країнах світу. Однак для ефективної організації цієї діяльності потрібне належне державне регулювання. У статті автори розглянуть історію створення нормативної бази космічного агентства України. Дослідження документів, що визначають нормативне регулювання процедур організації космічної діяльності дозволить авторам прослідкувати, з одного боку, становлення космічної індустрії незалежної України, з другого - виявити причини занепаду колись провідної у СРСР космічної галузі, наукові розробки, інтелектуальний потенціал і промислові активи якої залишилися на території незалежної України.

Згідно Ст. 4 Закону України від 15.11.1996 р. № 502/96-ВР «Про космічну діяльність» однієюз основних засад космічної діяльності в Україні визначене державне регулювання [Закон, 1997]. У Ст. 6 цього закону передбачається, що державне регулювання у цій сфері здійснюється через «Центральний орган виконавчої влади, що забезпечує формування державної політики у сфері космічної діяльності, в межах своєї компетенції» [Закон, 1997]. Адміністративно-правовий статус Центрального органу виконавчої влади у цій сфері визначається «Положенням про Державне космічне агентство України». П. 1 «Положення» зазначає: «Державне космічне агентство України (ДКА) є центральним органом виконавчої влади, діяльність якого спрямовується і координується Кабінетом Міністрів України та який забезпечує формування і реалізує державну політику у сфері космічної діяльності» [Положення, 2015].

Отже, Державне космічне агентство України поєднує у собі повноваження Центрального органу виконавчої влади як щодо формування, так і щодо реалізації державної політики у сфері космічної діяльності.

Однак історично так було не завжди. Вперше в Україні Центральний орган виконавчої влади у сфері космічної діяльності був створений Указом Президента України [Про створення, 1992]. На виконання цього Указу Кабінет Міністрів України прийняв «Положення про Національне космічне агентство України при Кабінеті Міністрів України», яке вперше регламентувало адміністративно-правовий статус 01.06.1992 Центрального органу виконавчої влади у сфері космічної діяльності [Положення, 1992]. Прийняте 01.06.1992 р., тобто до запровадження Закону України «Про космічну діяльність» чи іншого спеціального закону, Положення не грунтувалося на міцній законодавчій базі й неодноразово піддавалося змінам чи замінам на інший акт.

Як зазначає Леонід Бєлкін, в Україні, в історичному контексті, зміни у структурі Центрального органу виконавчої влади носили непослідовний характер. Вони не спираються на доктринальні та концептуальні напрацювання, зокрема, на офіційно схвалену Концепцію адміністративної реформи в Україні. Це призводило до постійних, іноді необгрунтованих змін у системі Центральних органів виконавчої влади, що спричиняло негативний вплив на їх діяльність [Бєлкін, 2014: 86]. 
State Space Agency of Ukraine: History of the Development of Normative Base by Yulia Iurynets

Отже, автори вважають актуальним дослідити, у якій мірі ця закономірність стосувалася Центрального органу виконавчої влади у сфері космічної діяльності, з наступною оцінкою впливу цього чинника на ефективність його діяльності.

\section{Виклад основного матеріалу}

Першим нормативним актом, що регулює сферу публічного управління у космічній галузі, був Указ Президента України «Про створення Національного космічного агентства України». У цьому Указі було вперше визначені назва та статус Агентства: «Національне космічне агентство України при Кабінеті Міністрів України» [Про створення, 1992]. У п. 2 цього Указу були також вперше сформульовані завдання Агентства, які, очевидно, на той момент розглядалися як ключові уцій сфері і які будуть досліджуватися нижче у порівнянні з іншими актами.

На виконання Указу Президента Кабінет Міністрів України прийняв Положення [Положення, 1992], яке, як зазначено вище, вперше регламентувало адміністративноправовий статус Центрального органу виконавчої влади у сфері космічної діяльності та яке визначало такий Центральний орган виконавчої влади як Національне космічне агентство України при Кабінеті Міністрів України. Натомість, за відсутності спеціального закону щодо космічної діяльності це Положення було позбавлене міцного законодавчого підгрунтя, лише у загальних рисах окреслювало адміністративно-правовий статус Агентства і неодноразово піддавалося змінам чи замінам на інший акт. Перелік ключових нормативно-правових актів, в контексті врегулювання адміністративно-правового статусу в частині назви, наведений у Таблиці 1.

Наведені дані свідчать про те, що правове регулювання адміністративно-правового статусу Центрального органу виконавчої влади у сфері космічної діяльності носить непослідовний і навіть колізійний характер. Наприклад, протягом одного періоду часу діють нормативно-правові акти різних видавників і навіть одного видавника, які по-різному, суперечливо, вирішують питання адміністративно-правового статусу. Зокрема, як видно з Таблиці 1, у певні періоди часу одночасно діяли Положення [Положення, 1992] і Положення [Положення, 1997]; Положення [Положення, 1997] і Положення [Положення, 1997]; Положення [Положення, 2011] і Положення [Положення, 2015]. Наведенні Положення попарно по-різному регулюють адміністративно-правовий статус, починаючи з назви. Більше того, Положення [Положення, 2011] рахується чинним і дотепер (кінець 2018 р.), незважаючи на прийняття Положення [Положення, 2015].

Суперечності, описані вище, пов'язані із тим, що українське право системно не вирішило питання узгодження прийняття/скасування підзаконних нормативно-правових актів у випадку перерозподілу конституційних повноважень між Президентом і Кабінетом Міністрів України. В результаті суб'єкт нормотворення, що отримав повноваження, приймає своє Положення, а суб'єкт, який втратив відповідні повноваження, не поспішає скасувати свої застарілі акти. Це чітко проглядається з дат, наведених у Таблиці 1, які практично співпадають з прийняттям (відновленням) редакцій Конституції України.

Варто зазначити, що якщо описані вище суперечності об'єктивно пов'язані з недоліками правового регулювання, то інші ситуації пов'язані виключно із правовим нігілізмом чи службовою недбалістю видавників. Серед таких наведемо наступні приклади:

По-перше, досі вважається чинним Указ Президента України «Про створення Національного космічного агентства України» [Про створення, 1992], хоча після ньо- 
го приймалося, як мінімум, три Укази Президента України, що суттєво змінюють адміністративно-правовий статус Агентства:

1. «Положення про Національне космічне агентство України» [Положення, 1997];

2. «Про оптимізацію системи центральних органів виконавчої влади» [Про оптимізацію, 2010];

3. «Положення про Державне космічне агентство України» [Положення, 2011].

По-друге, Указом Президента «Про оптимізацію системи центральних органів виконавчої влади» від 09.12.2010 р. змінена назва космічного агентства України 3 Національного на Державне космічне агентство України [Про оптимізацію, 2010]. Однак тільки 08.04.2011 р. Було прийняте нове Положення [Положення, 2011], в якому назва Агентства використовується в редакції Указу Президента України [Про оптимізацію, 2010]. Більше того, перейменування на підставі Указу Президента [Про оптимізацію, 2010] суперечило Закону України [Закон, 1997], де Агентство продовжувалося називатися «Національне космічне агентство України». Тільки у Законі України «Про внесення змін до Закону України «Про космічну діяльність»» (набрав чинності 06.01.2012р.) назва «Національне космічне агентство України» була змінена на нейтральну назву «Центральний орган виконавчої влади з питань космічної діяльності» [Про внесення, 2012]. Тобто, закон підігнали під підзаконний акт.

Таблиця 1. Правові акти в контексті врегулювання адміністративно-правового статусу Центрального органу виконавчої влади у сфері космічної діяльності в частині назви

\begin{tabular}{|c|c|c|c|c|c|c|c|}
\hline \multicolumn{3}{|c|}{$\begin{array}{l}\text { За ЗУ [Закон, 1997] } \\
\text { (з урахуванням змін) }\end{array}$} & \multicolumn{5}{|c|}{ За положеннями (підзаконними актами) } \\
\hline Назва ЦОВВ & $\begin{array}{l}\text { Початок } \\
\text { періоду }\end{array}$ & $\begin{array}{c}\text { Кінець } \\
\text { періоду, } \\
\text { підстава }\end{array}$ & Видавник & Джерело & $\begin{array}{l}\text { Назва } \\
\text { ЦОВВ }\end{array}$ & $\begin{array}{l}\text { Початок } \\
\text { періоду }\end{array}$ & $\begin{array}{c}\text { Кінець } \\
\text { періоду, } \\
\text { підстава }\end{array}$ \\
\hline & & & Президент & $\begin{array}{c}\text { Про } \\
\text { створ, } \\
1992]\end{array}$ & НКАУ & 29.02 .1992 & - \\
\hline & & & КМУ & $\begin{array}{c}\text { [Положен- } \\
\text { ня, 1992] }\end{array}$ & $\begin{array}{c}\text { НКАУ при } \\
\text { КМУ }\end{array}$ & 01.06 .1992 & $\begin{array}{c}18.05 .1998 \\
\text { [Про ви- } \\
\text { знання, } \\
1998] \\
\end{array}$ \\
\hline \multirow[t]{3}{*}{ НКАУ } & 15.11 .1996 & $\begin{array}{c}06.01 .2012 \\
\text { [Про } \\
\text { внесення, } \\
\text { 2012] } \\
\end{array}$ & & & & & \\
\hline & & & Президент & $\begin{array}{c}\text { [Положен- } \\
\text { ня, } 1997 \text { ] }\end{array}$ & НКАУ & 22.07 .1997 & $\begin{array}{c}09.12 .2010 \\
\text { [Про } \\
\text { оптим., } \\
2010]\end{array}$ \\
\hline & & & Президент & $\begin{array}{c}\text { [Про } \\
\text { оптим., } \\
2010]\end{array}$ & ДКАУ & 09.12 .2010 & - \\
\hline
\end{tabular}


State Space Agency of Ukraine: History of the Development of Normative Base by Yulia Iurynets

\begin{tabular}{|c|c|c|c|c|c|c|c|}
\hline & & & КМУ & $\begin{array}{c}\text { [Положен- } \\
\text { ня, 2006] }\end{array}$ & НКАУ & 13.12 .2006 & $\begin{array}{c}14.05 .2015 \\
\text { [Поло- } \\
\text { жен., } \\
\text { 2015] } \\
\end{array}$ \\
\hline & & & Президент & \begin{tabular}{|c|} 
[Положен- \\
ня, 2011]
\end{tabular} & ДКАУ & 08.04.2011 & - \\
\hline $\begin{array}{c}\text { ЦОВВ з питань кос- } \\
\text { мічної діяльності }\end{array}$ & 06.01 .2012 & $\begin{array}{c}11.12 .2012 \\
\text { [Про } \\
\text { внесення, } \\
\text { 2014] }\end{array}$ & & & & & \\
\hline $\begin{array}{c}\text { ЦОВВ, що забез- } \\
\text { печує формування } \\
\text { державної політики } \\
\text { у сфері космічної } \\
\text { діяльності }\end{array}$ & \multirow{2}{*}{11.12 .2012} & & & & & & \\
\hline \multirow[t]{2}{*}{$\begin{array}{c}\text { ЦОВВ, що реалізує } \\
\text { державну політику } \\
\text { у сфері космічної } \\
\text { діяльності }\end{array}$} & & & & & & & \\
\hline & & & КМУ & \begin{tabular}{|c|} 
[Положен- \\
ня, 2015]
\end{tabular} & ДКАУ & 14.05 .2015 & - \\
\hline
\end{tabular}

Варто зазначити, що такі суперечності значно ускладнюють правове регулювання в космічній галузі, створюючи штучні колізії. Правда в теорії права вважається що у випадку наявності норм однакового рівня, які по-різному врегульовують одні й ті самі питання, підлягають застосуванню норми, що набрали чинності пізніше, чи прийняті пізніше тощо [Малишев \& Москалюк, 2010]. Однак, по-перше, це правило законодавчо не оформлене і тому необов'язкове для застосування; по-друге, у випадку колізії Указу Президента та Постанови Кабінету Міністрів України незрозуміло, яка норма вище, 3 огляду на розподіл повноважень. Зазначене створює свавілля у правозастосуванні.

При цьому слід врахувати, що вказані колізії стосуються не тільки (i, можливо, не стільки) назви, скільки інших складових адміністративно-правового статусу, зокрема, загальної характеристики статусу та сукупності повноважень. У таблиці 2 наведені порівняння загальної характеристики статусу Центрального органу виконавчої влади у сфері космічної діяльності за різними нормативно-правовими актами та у різний період часу. При цьому джерела інформації та прийняті часові періоди відповідають наведеним у Таблиці 1.

Наведені дані свідчать про те, що, як вже зазначено вище, різні нормативно-правові акти, які різним чином надають загальної характеристики статусу Центрального органу виконавчої влади у сфері космічної діяльності, перетинаються у часі. Це стосується, зокрема, попарно Положення [Положення, 1992] та Положення [Положення, 1997]; Положення [Положення, 1997] та Положення [Положення, 2006]; Положення [Положення, 2006] та Положення [Положення, 2011]; Положення [Положення, 2011] та Положення [Положення, 2015]. При цьому попарне порівняння характеристики статусу, викладеної у відповідних рядках, свідчить про різну, іноді дуже відмінну одна від одної характеристики статусу. При цьому попарне порівняння характеристики статусу, 
викладеної у відповідних рядках, свідчить про різну, іноді дуже відмінну одна від одної характеристики статусу. Тобто, як і у описаному вище випадку назви, в один і той же період часу діяли суттєво різні характеристики статусу. Натомість принципово, що їх об'єднує, це визначення Агентства як Центрального органу виконавчої влади.

Аналогічна ситуація складається із завданнями. Так, наприклад, вже згадувалося, що у період з 22.07.1997 р. по 18.05.1998 р. одночасно діяли і Указ Президента України [Про створення, 1992], і Положення [Положення, 1997], при чому обидва акти видавав один орган - Президент України. Однак у цих документах завдання Агентства визначалися геть по іншому, що можна порівняти з Таблиці 3.

Таблиця 2. Загальна характеристика статусу Центрального органу виконавчої влади у сфері космічної діяльності

\begin{tabular}{|c|c|c|c|}
\hline $\begin{array}{c}\text { № } \\
\Pi / \Pi\end{array}$ & Джерело & Період часу & Загальна характеристика статусу \\
\hline 1. & $\begin{array}{c}\text { [Положення, } \\
1992]\end{array}$ & \begin{tabular}{c|}
01.06 .1992 \\
- \\
18.05 .1998
\end{tabular} & $\begin{array}{l}\text { НКАУ є центральним органом державної виконавчої влади, } \\
\text { підвідомчим КМУ. Агентство забезпечує розробку та реаліза- } \\
\text { цію державної політики у галузі дослідження й використання } \\
\text { космічного простору і несе відповідальність за ефективне ви- } \\
\text { користання відповідного наукового та науково-технічного по- } \\
\text { тенціалу України }\end{array}$ \\
\hline 2. & $\begin{array}{c}\text { [Положення, } \\
\text { 1997] }\end{array}$ & $\begin{array}{c}22.07 .1997 \\
- \\
08.04 .2011\end{array}$ & $\begin{array}{l}\text { НКАУ є центральним органом виконавчої влади зі спеціальним } \\
\text { статусом, який забезпечує реалізацію державної політики у га- } \\
\text { лузі космічної діяльності, здійснює керівництво дорученою } \\
\text { йому сферою управління, несе відповідальність за стан її роз- } \\
\text { витку. Діяльність НКАУ спрямовується і координується КМУ }\end{array}$ \\
\hline 3. & $\begin{array}{c}\text { [Положення, } \\
2006]\end{array}$ & \begin{tabular}{c|}
13.12 .2006 \\
- \\
14.05 .2015
\end{tabular} & $\begin{array}{l}\text { НКАУ є центральним органом виконавчої влади, який забез- } \\
\text { печує реалізацію державної політики у сфері космічної діяль- } \\
\text { ності та несе відповідальність за стан іiі розвитку. Діяльність } \\
\text { НКАУ спрямовується і координується КМУ }\end{array}$ \\
\hline 4. & $\begin{array}{c}\text { [Положення, } \\
\text { 2011] }\end{array}$ & $\begin{array}{l}08.04 .2011 \\
(\text { не } \\
\text { скасоване) }\end{array}$ & $\begin{array}{l}\text { ДКАУ є центральним органом виконавчої влади, діяльність } \\
\text { якого спрямовується і координується КМУ. ДКАУ входить до } \\
\text { системи органів виконавчої влади, є головним органом у сис- } \\
\text { темі центральних органів виконавчої влади у формуванні та } \\
\text { забезпеченні реалізації державної політики у сфері космічної } \\
\text { діяльності }\end{array}$ \\
\hline 5. & $\begin{array}{c}\text { [Положення, } \\
2015]\end{array}$ & $\begin{array}{c}14.05 .2015 \\
\text { по } \\
\text { теперішній } \\
\text { час }\end{array}$ & $\begin{array}{l}\text { ДКАУ є центральним органом виконавчої влади, діяльність } \\
\text { якого спрямовується і координується КМУ та який забезпечує } \\
\text { формування і реалізує державну політику у сфері космічної ді- } \\
\text { яльності. }\end{array}$ \\
\hline
\end{tabular}


State Space Agency of Ukraine: History of the Development of Normative Base by Yulia Iurynets

Таблиця 3. Порівняння завдань НКАУ за Указом Президента

[Про створення, 1992] та Положення [Положення, 1997]

\begin{tabular}{|c|c|}
\hline $\begin{array}{c}\text { Завдання за пунктом } 2 \text { Указу } \\
\text { [Про створення, 1992] }\end{array}$ & $\begin{array}{c}\text { Завдання за пунктом п. } 3 \text { Положення } \\
\text { [Положення, 1997] }\end{array}$ \\
\hline $\begin{array}{l}\text { Розробка концептуальних основ державної } \\
\text { політики в галузі дослідження і використання } \\
\text { космічного простору }\end{array}$ & $\begin{array}{l}\text { Розробка концептуальних основ державної } \\
\text { політики в галузі дослідження і використан- } \\
\text { ня космічного простору в мирних цілях та в } \\
\text { інтересах безпеки держави }\end{array}$ \\
\hline $\begin{array}{l}\text { Підготовка пропозицій та рекомендацій Прези- } \\
\text { денту України і КМУ з питань дослідження і } \\
\text { використання космічного простору }\end{array}$ & \\
\hline \multirow[t]{2}{*}{$\begin{array}{l}\text { Координація діяльності органів державної ви- } \\
\text { конавчої влади, науково-дослідних установ, } \\
\text { підприємств і організацій космічної галузі з пи- } \\
\text { тань організації та проведення космічних робіт }\end{array}$} & $\begin{array}{l}\text { Забезпечення організації і розвитку космічної } \\
\text { діяльності в Україні та під юрисдикцією Украї- } \\
\text { ни поза ії межами }\end{array}$ \\
\hline & $\begin{array}{l}\text { Сприяння підвищенню обороноздатності дер- } \\
\text { жави та національної безпеки з використанням } \\
\text { космічних засобів }\end{array}$ \\
\hline $\begin{array}{l}\text { Організація міжнародного та міждержавного } \\
\text { співробітництва і здійснення контролю за до- } \\
\text { держанням міжнародно-правових норм } 3 \text { пи- } \\
\text { тань дослідження і використання космічного } \\
\text { простору }\end{array}$ & $\begin{array}{l}\text { Розвиток співробітництва України з іншими } \\
\text { державами та міжнародними організаціями у } \\
\text { космічній галузі }\end{array}$ \\
\hline $\begin{array}{l}\text { Організація робіт фундаментального та при- } \\
\text { кладного характеру в космічній галузі }\end{array}$ & $\begin{array}{l}\text { Розроблення й реалізація пропозицій щодо нау- } \\
\text { кового, виробничо-технічного та фінансов-- } \\
\text { економічного розвитку космічної галузі }\end{array}$ \\
\hline $\begin{array}{l}\text { Фінансування робіт по дослідженню } \mathrm{i} \\
\text { використанню космічного простору }\end{array}$ & \\
\hline
\end{tabular}

Зазначимо, що у Положення [Положення, 1997], на виконання норм Закону України [Закон, 1997], вперше згадується про роль космічної діяльності в підвищенні обороноздатності та національної безпеки України.

Більш розгалужене порівняння завдань і повноважень за різними нормативноправовими актами в історичному контексті може бути предметом подальших наукових розвідок.

Отже, знаходить своє підтвердження, що у сфері космічної діяльності зміни щодо Центрального органу виконавчої влади носили непослідовний, певною мірою хаотичний характер. Як зазначає Леонід Бєлкін, це не тільки не сприяє подоланню бюрократизму, а навпаки, приводить до його підсилення [Бєлкін, 2014: 86]. Зокрема, знижується загальний рівень компетентності, оскільки кваліфіковані спеціалісти не можуть і не хочуть працювати у таких нестабільних умовах, втрачаються позитивні напрацювання попередників. 3 іншого боку, постійні реорганізації створюють більше шансів залиши- 
тися на роботі тим, хто краще догоджає «начальству». За таких умов годі сподіватися на підвищення якості роботи державного апарату та ії законності.

Варто зазначити, що описане адміністративно-правове регулювання віддзеркалює недбале ставлення української влади до розвитку космічної діяльності, що знаходить відображення і в ії негативних результатах і $є$ також відображенням недбалого ставлення до самого космічного агентства України як уповноваженого органу влади. Так, Юрій Бухун вказує, що обмежене державне фінансування продемонструвало свою неспроможність розвивати галузь [Бухун, 2016: 254-255].

\section{Висновки}

За результатами дослідження автори дійшли наступних висновків:

1. Адміністративно-правове регулювання у сфері космічної діяльності започатковане Указом Президента України від 29.02.1992 р. та прийнятим на його розвиток Положенням від 01.06.1992 р. Але ці акти не грунтувалися на міцній законодавчій базі й неодноразово піддавалися змінам чи замінам на інші акти. Натомість Державне (до 09.12.2010 p. - Національне) космічне Агентство мало постійний статус центрального органу виконавчої влади.

2. Адміністративно-правове регулювання у сфері космічної діяльності характеризується непослідовністю, що свідчить про відсутність концепції розвитку галузі. Тому підзаконні акти, що приймалися, часто носили суб’ єктивний характер, суперечили один одному, а подекуди і нормам закону. Запропонований у Законі України [Про внесення, 2014] розподіл повноважень між Центральним органом виконавчої влади, що забезпечує формування державної політики у сфері космічної діяльності, та Центральним органом виконавчої влади, що реалізує державну політику у сфері космічної діяльності, залишився формальним, оскільки обидві групи повноважень продовжує виконувати єдине Державне космічне агентство України.

3. Недоліки в публічному управлінні космічною галуззю відбиваються i на недостатньому бюджетному, фінансовому та господарському управлінні.

\section{Література}

Бєлкін, Леонід. Забезпечення законності в діяльності органів виконавчої влади: адміністративно-правовий вимір. Ужгород: Бреза, 2014.

Бухун, Юрій. Забезпечення ефективного фінансування підприємств космічної галузі України. Економічний форум. 2, 2016: 254-258.

Закон України «Про космічну діяльність». Відомості Верховної Ради Украӥни (ВВР), 1 , 1997. ст. 2

Малишев, Б. В., Москалюк, О. В. Застосування норм права (теорія і практика). Київ: Реферат, 2010.

Положення про Національне космічне агентство України при Кабінеті Міністрів України. Постанова Кабінету Міністрів України від 01.06.1992 p. № 304. http:// zakon3.rada.gov.ua/ laws/ show/ 304-92-\%D0\%BF

Положення про Наџіональне космічне агентство України. Постанова Кабінету Міністрів України від 13.12.2006 р. № 1722. http://zakon3.rada.gov.ua/laws/show/1722-2006$\% \mathrm{D} 0 \% \mathrm{BF}$ 
State Space Agency of Ukraine: History of the Development of Normative Base by Yulia Iurynets

Положення про Наиіональне космічне агентство України. Указ Президента України від 22.07.1997 p. № 665/97. http://zakon3.rada.gov.ua/laws/show/665/97

Положення про Національне космічне агентство України. Постанова Кабінету Міністрів України від 13.12.2006 p. № 1722. http://zakon3.rada.gov.ua/laws/show/1722-2006$\% \mathrm{D} 0 \% \mathrm{BF}$

Положення про Державне космічне агентство України. Указ Президента України від 08.04.2011 p. № 442/2011. http://zakon3.rada.gov.ua/laws/show/442/2011

Положення про Державне космічне агентство України. Постанова Кабінету Міністрів України від 14 травня 2015 р. № 281. https://zakon.rada.gov.ua/laws/show/281-2015$\% \mathrm{D} 0 \% \mathrm{BF}$

Про визнання такими, щзо втратили чинність, деяких постанов Кабінету Міністрів Украӥни з питань діяльності Наиіонального космічного агентства. Постанова Кабінету Міністрів України від 18.05.1998 р. № 682. http: //zakon3.rada.gov.ua/ laws/show/682-98-\%D0\%BF

Про внесення змін до Закону України «Про космічну діяльність». Закон України від 09.12.2011 p. № 4102-VI. Відомості Верховної Ради України, 2012. № 28. Ст. 308. Про внесення змін до деяких законодавчих актів України... Відомості Верховної Ради України. 2014. № 5. Ст. 62.

Про оптимізаиію системи иентральних органів виконавчої влади. Указ Президента України від 09.12.2010 p. № 1085/2010. http://zakon4.rada.gov.ua/laws/ show/1085/2010

Про створення Національного космічного агентства Украӥни. Указ Президента України від 29.02.1992 p. № 117. http://zakon3.rada.gov.ua/laws/show/117/92

\section{[L] References}

Bielkin, Leonid. Zabezpechennia zakonnosti $\mathrm{v}$ diialnosti orhaniv vykonavchoi vlady: administratyvno-pravovyi vymir. Uzhhorod: Breza, 2014.

Bukhun, Yurii. Zabezpechennia efektyvnoho finansuvannia pidpryiemstv kosmichnoi haluzi Ukrainy. Ekonomichnyi forum. 2, 2016: 254-258.

Zakon Ukrainy «Pro kosmichnu diialnist». Vidomosti Verkhovnoi Rady Ukrainy (VVR), 1, 1997. st. 2

Malyshev, B. V., Moskaliuk, O. V. Zastosuvannia norm prava (teoriia i praktyka). Kyiv: Referat, 2010.

Polozhennia pro Natsionalne kosmichne ahentstvo Ukrainy pry Kabineti Ministriv Ukrainy. Postanova Kabinetu Ministriv Ukrainy vid 01.06.1992 r. № 304. http://zakon3.rada. gov.ua/ laws/ show/ 304-92-\%D0\%BF

Polozhennia pro Natsionalne kosmichne ahentstvo Ukrainy. Postanova Kabinetu Ministriv Ukrainy vid 13.12.2006 r. № 1722. http://zakon3.rada.gov.ua/laws/show/1722-2006$\% \mathrm{D} 0 \% \mathrm{BF}$

Polozhennia pro Natsionalne kosmichne ahentstvo Ukrainy. Ukaz Prezydenta Ukrainy vid 22.07.1997 r. № 665/97. http://zakon3.rada.gov.ua/laws/show/665/97

Polozhennia pro Natsionalne kosmichne ahentstvo Ukrainy. Postanova Kabinetu Ministriv Ukrainy vid 13.12.2006 r. № 1722. http://zakon3.rada.gov.ua/laws/show/1722-2006$\% \mathrm{D} 0 \% \mathrm{BF}$ 
Polozhennia pro Derzhavne kosmichne ahentstvo Ukrainy. Ukaz Prezydenta Ukrainy vid 08.04.2011 r. № 442/2011. http://zakon3.rada.gov.ua/laws/show/442/2011

Polozhennia pro Derzhavne kosmichne ahentstvo Ukrainy. Postanova Kabinetu Ministriv Ukrainy vid 14 travnia 2015 r. № 281. https://zakon.rada.gov.ua/laws/show/281-2015$\% \mathrm{D} 0 \% \mathrm{BF}$

Pro vyznannia takymy, shcho vtratyly chynnist, deiakykh postanov Kabinetu Ministriv Ukrainy z pytan diialnosti Natsionalnoho kosmichnoho ahentstva. Postanova Kabinetu Ministriv Ukrainy vid 18.05.1998 r. № 682. http: //zakon3.rada.gov.ua/laws/show/682$98-\% \mathrm{D} 0 \% \mathrm{BF}$

Pro vnesennia zmin do Zakonu Ukrainy «Pro kosmichnu diialnist». Zakon Ukrainy vid 09.12.2011 r. № 4102-VI. Vidomosti Verkhovnoi Rady Ukrainy, 2012. № 28. St. 308.

Pro vnesennia zmin do deiakykh zakonodavchykh aktiv Ukrainy... Vidomosti Verkhovnoi Rady Ukrainy. 2014. № 5. St. 62.

Pro optymizatsiiu systemy tsentralnykh orhaniv vykonavchoi vlady. Ukaz Prezydenta Ukrainy vid 09.12.2010 r. № 1085/2010. http://zakon4.rada.gov.ua/laws/show/1085/2010

Pro stvorennia Natsionalnoho kosmichnoho ahentstva Ukrainy. Ukaz Prezydenta Ukrainy vid 29.02.1992 r. № 117. http://zakon3.rada.gov.ua/laws/show/117/92 